\title{
Feeding habits of Enyalius perditus (Squamata: Leiosauridae) in an Atlantic Forest remnant in southeastern Brazil
}

Thiago Maia-Carneiro ${ }^{1}$, Tatiana Motta-Tavares ${ }^{1}$, Davor Vrcibradic ${ }^{2}$, Mara C. Kiefer ${ }^{3}$, Thiago A. Dorigo ${ }^{1}$, Carlos F. D. Rocha ${ }^{1}$, and Monique Van Sluys ${ }^{1}$

\footnotetext{
${ }^{1}$ Departamento de Ecologia, Universidade do Estado do Rio de Janeiro, Rua São Francisco Xavier 524, 20550-011, Rio de Janeiro, RJ, Brazil. E-mail: tmaiacarneiro@gmail.com.

${ }^{2}$ Departamento de Zoologia, Universidade Federal do Estado do Rio de Janeiro. Av. Pasteur 458, Urca, 22240-290, Rio de Janeiro, RJ, Brazil.

${ }^{3}$ Departamento de Biologia Geral, Instituto de Biologia, Universidade Federal Fluminense, Caixa Postal 100436, Centro, 24020-971, Niterói, RJ, Brazil.
}

\begin{abstract}
Feeding habits of Enyalius perditus (Squamata: Leiosauridae) in an Atlantic Forest remnant in southeastern Brazil. In the present study, we aimed to provide information regarding feeding habits and other ecological aspects of Enyalius perditus in an Atlantic Forest remnant in the state of Rio de Janeiro, southeastern Brazil. Enyalius perditus individuals in Rio de Janeiro fed predominantly upon arthropods such as caterpillars, isopods, and spiders, as is typical of lizards in the genus. There were no pronounced variations in the main types of prey consumed between this and other populations of $E$. perditus studied in spite of potential differences in local food supplies between environments. The individuals consumed fragments of dead leaves, ingested prey commonly found in leaf litter (e.g., Isopoda and Coleoptera larvae), and were sometimes found on the ground or captured in pit-fall traps during fieldwork, which suggests that these lizards use the forest floor leaf litter for foraging and other activities, although they also use perches above ground level. Our study provides additional information and reinforces the idea of the use of both the vegetation and the leaf litter of forest floor by lizards of the genus Enyalius.
\end{abstract}

Keywords: diet, leaf litter, lizard, microhabitat use, perch height. 


\begin{abstract}
Resumo
Hábitos alimentares de Enyalius perditus (Squamata: Leiosauridae) em um fragmento de Mata Atlântica no sudeste do Brasil. O objetivo do presente estudo foi fornecer informações sobre hábitos alimentares e outros aspectos ecológicos do lagarto Enyalius perditus em um fragmento de Mata Atlântica no estado do Rio de Janeiro, sudeste do Brasil. No Rio de Janeiro, os indivíduos de E. perditus alimentaram-se predominantemente de artrópodes, como lagartas, isópodes e aranhas, como é típico de lagartos desse gênero. Não houve variação pronunciada nos principais tipos de presas consumidas entre essa e outras populações de E. perditus estudadas, apesar de haver diferenças potenciais nos suprimentos alimentares entre ambientes. Os indivíduos consumiram fragmentos de folhas mortas, ingeriram presas comumente encontradas na serapilheira (e.g., Isopoda e larvas de Coleoptera) e foram algumas vezes encontrados no chão ou capturados em armadilhas-de-queda durante os trabalhos de campo, o que sugere que esses lagartos utilizam a serapilheira do chão da floresta para o forrageio e outras atividades, embora também utilizem poleiros acima do nível do chão. Nosso estudo fornece informações adicionais e reforça a ideia do uso tanto da vegetação como do chão da floresta por lagartos do gênero Enyalius.
\end{abstract}

Palavras-chave: altura do poleiro, dieta, lagarto, serapilheira, uso de micro-habitats.

\section{Introduction}

The genus Enyalius Wied, 1821 (Leiosauridae) occurs in Amazonian and Atlantic Forests, Caatinga, and Cerrado and includes ten species (Costa and Bérnils, 2014). These small to medium-sized diurnal lizards have arboreal habits, but also can be found on the forest floor (e.g., E. leechii: Vitt et al. 1996, E. bilineatus: Zamprogno et al. 2001, E. iheringii: Rautenberg and Laps 2010, E. perditus: BarretoLima et al. 2013, E. brasiliensis: Dorigo et al. 2014). Studies on the diet of Enyalius species revealed that these lizards fed predominantly on arthropods that inhabit both the leaf litter of the forest floor and the vegetation above ground level (Vanzolini 1972, Vitt et al. 1996, Zamprogno et al. 2001, Van Sluys et al. 2004, Teixeira et al. 2005, Sousa and Cruz 2008, Rautenberg and Laps 2010, Sturaro and Silva 2010, Barreto-Lima and Sousa 2011, BarretoLima et al. 2013, Dorigo et al. 2014). Enyalius perditus Jackson, 1978 (Figure 1) is a diurnal lizard that occurs in the Brazilian Atlantic Forest in the states of Paraná, São Paulo, Minas Gerais, and Rio de Janeiro (Jackson 1978, Souza et al. 2000). Information on the biology of E. perditus has increased in recent years, with studies available regarding activity, feeding habits and space use (Souza and Cruz 2008, Barreto-Lima 2009, Sturaro and Silva 2010, Barreto-Lima and Sousa 2011, Barreto-Lima et al. 2013), morphology (Sturaro and Silva 2010, BarretoLima and Sousa 2011), reproductive aspects (Barreto-Lima and Sousa 2006, Sturaro and Silva 2010), parasitism (Durette-Desset et al. 2006, Sousa et al. 2007, Vrcibradic et al. 2008, Barreto-Lima et al. 2012), and description of skin shedding (Sousa et al. 2000). Few populations of E. perditus in the Atlantic Forest have been the subjects of ecological studies, and no populations in the state of Rio de Janeiro were investigated. Here, we add information on feeding habits and microhabitat use of E. perditus from an Atlantic Forest remnant in the state of Rio de Janeiro.

\section{Materials and Methods}

\section{Study Area}

Fieldwork was carried out in Santo Antônio da Aliança farm in an area partly included in the Santuário de Vida Silvestre da Serra da 


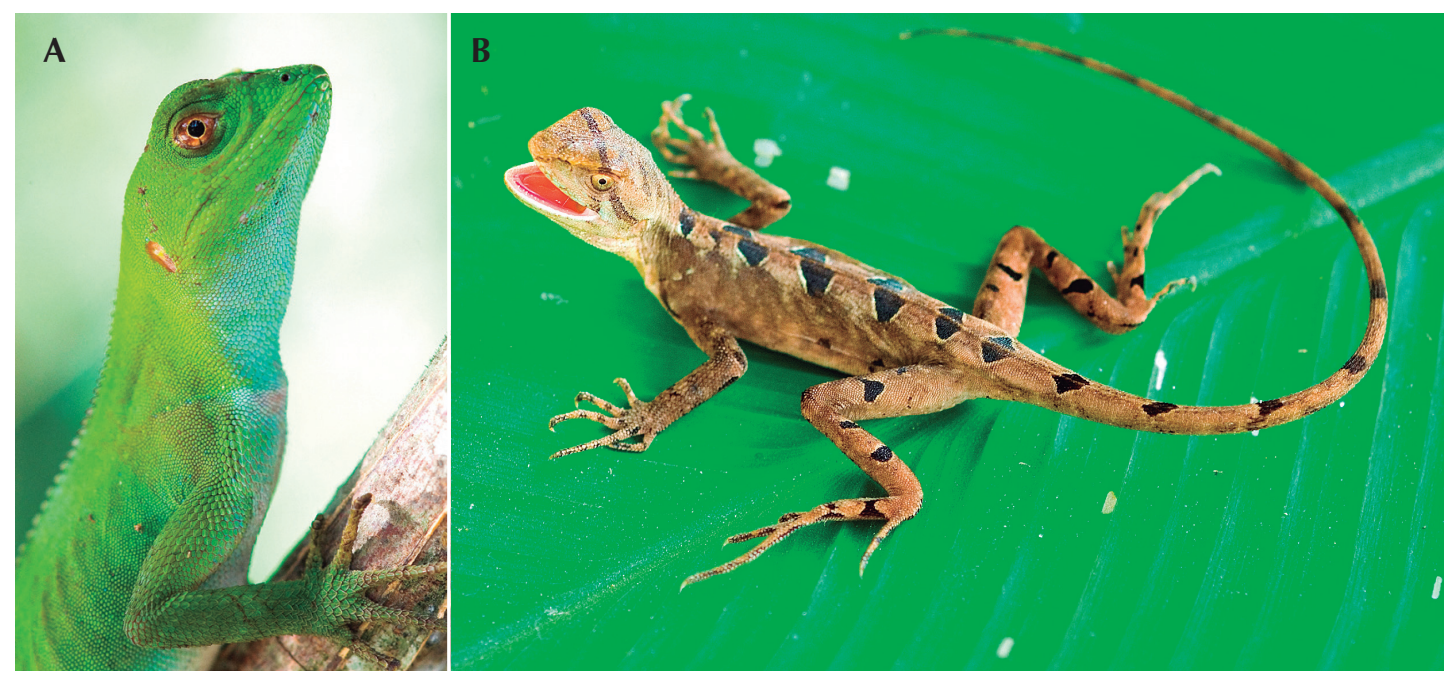

Figure 1. A male (A) and a female (B) of Enyalius perditus from Serra da Concórdia, state of Rio de Janeiro, southeastern Brazil. Photos: Robert Vámos.

Concórdia (hereafter Serra da Concórdia, 22²2' $\left.\mathrm{S}, 43^{\circ} 47^{\prime} \mathrm{W}\right)$, located in the municipalities of Barra do Piraí and Valença, state of Rio de Janeiro, southeastern Brazil. The farm has a total area of 295 ha, with elevations ranging between 600 and $925 \mathrm{~m}$ a.s.l. (Attias et al. 2009). Vegetation is predominantly composed of tropical semi-deciduous seasonal forest (Attias et al. 2009). Mean annual temperature in the region is $20.4^{\circ} \mathrm{C}$ and varies from 10.8 to $28.7^{\circ} \mathrm{C}$, with mean annual precipitation of $1,469 \mathrm{~mm}$ (Attias et al. 2009).

\section{Data Collection and Analytical Procedures}

Lizards were collected during herpetological surveys carried out in April 2005, using three sampling methods: visual encounter surveys (Crump and Scott Jr. 1994), pitfall traps with drift fences (Corn 1994), and plots or quadrats (Jaeger and Inger 1994). Visual encounter surveys were performed by time-constrained transects (30 min) undertaken during the day, twilight, and night periods, totaling $60 \mathrm{~h}(20 \mathrm{~h}$ at each period) of active search during five days. For the plot method, we established 18 quadrats of $5 \times 5 \mathrm{~m}\left(25 \mathrm{~m}^{2}\right)$ on the ground of the forest during the afternoon, totaling $450 \mathrm{~m}^{2}$ of forest floor sampled during five days. We marked the corners of each plot using wooden stakes and enclosed the area with a $50 \mathrm{~cm}$ high soft plastic fence whose base was buried or attached to the ground. At night, a group of five persons wearing headlamps, moving on hands and knees, side-byside, carefully searched each plot. The three pitfall trap systems consisted of ten 30-liter buckets buried approximately $5 \mathrm{~m}$ apart from one another, with soft plastic drift fences about $50 \mathrm{~cm}$ high extended between them. Six buckets were set in line and the remaining four placed at opposite ends of the fence, perpendicularly to the main axis. Buckets were checked once per day, always in the morning, over 20 days, totaling 600 buckets-days of sampling effort. Individuals of Enyalius perditus collected by the described methods and during occasional encounters (without using any particular method) were later killed with ether, fixed in $10 \%$ 
formalin solution, and preserved in $70 \%$ alcohol. We recorded the type of microhabitats and the height of perches used by the lizards found during visual encounter surveys or opportunistically. We considered leaf litter to be the microhabitat of individuals captured in pitfall traps. In addition, we scored lizards sighted on leaf litter or captured using pitfalls as having a perch height of zero.

The preserved lizards were measured with a caliper (precision of $0.1 \mathrm{~mm}$ ) in their snout-vent length (SVL) and jaw width (JW), had their body mass measured using an electronic balance (precision of $0.00001 \mathrm{~g}$ ), and were then dissected for analyses of their stomach contents. Diet was analyzed in terms of number, volume $\left(\mathrm{mm}^{3}\right)$, and frequency of occurrence of each prey item. Prey items were identified to the level of Order (or Family, in the case of Formicidae) following Johnson and Triplehorn (2004). Each prey item was measured for length and width using a caliper (precision of $0.1 \mathrm{~mm}$ ), and those measurements were used to estimate prey volume $\left(\mathrm{mm}^{3}\right)$ through the formula of the ovoidspheroid [V $\left.=4 / 3 \pi(\mathrm{L} / 2)(\mathrm{W} / 2)^{2}\right]$ (Dunham 1983). Frequency of occurrence was estimated as the proportion of stomachs containing a given type of prey item. Descriptive statistics provided throughout the text represent means \pm one SD. All lizards were deposited at the reptile collection of the Museu Nacional, Universidade Federal do Rio de Janeiro (voucher numbers MNRJ 25536-46).

\section{Results}

Eleven individuals of $E$. perditus were collected. Of these, six were adult females, one was an adult male, and four were juvenile females. Age classes (juvenile or adult) were based on minimum SVL of mature E. perditus individuals reported by Sturaro and Silva (2010). The values of SVL, JW, and body mass of the specimens averaged $74.2 \pm 11.1 \mathrm{~mm}$ (range: $63.3-100.2 \mathrm{~mm}, N=11$ ), $13.9 \pm 1.8 \mathrm{~mm}$ (range: $11.8-17.5 \mathrm{~mm}, N=11$ ), and $12.8 \pm 6.5$ g (range: $6.8-29.5 \mathrm{~g}, N=11$ ), respectively.
Three individuals (27.3\%) had empty stomachs and the remaining lizards had consumed mainly arthropods (Table 1). Mean number of identifiable food items per stomach was $7.1 \pm 7.5$ (range: $1-22, N=57$ ), and mean length and mean width of prey consumed by the lizards were $7.2 \pm 6.5$ (range: $1.5-26.2 \mathrm{~mm}, N=$ 57) and $2.3 \pm 1.6 \mathrm{~mm}$ (range: $0.6-9.3 \mathrm{~mm}, N=$ 57), respectively. Mean volume of prey items was $53.9 \pm 123.0 \mathrm{~mm}^{3}$ (range: $0.26-635.9 \mathrm{~mm}^{3}$, $N=57)$. In numerical terms, Isopoda (52.6\%) and Lepidoptera larvae $(17.5 \%)$ were the most prevalent prey in our samples (Table 1). Regarding proportional volume, the most important items were Lepidoptera larvae $(32.1 \%)$ and Araneae (17.8\%). In terms of frequency of occurrence, Lepidoptera larvae and Isopoda were the most frequent prey in the stomachs, occurring in $75 \%$ and $37.5 \%$ of the individuals, respectively (Table 1). Lizards for which microhabitat data were recorded were captured on branches of trees or shrubs $(N=6)$, and on leaf litter $(N=3)$, and the height of perches they used averaged $80.0 \pm 77.9 \mathrm{~cm}$, varying between 0 and $200 \mathrm{~cm}$ $(N=9)$. Interestingly, all lizards found perched on vegetation were at rest during the crepuscular and nocturnal periods, whereas the three individuals collected in activity (including two captured in pitfall traps) were on the ground.

\section{Discussion}

Enyalius perditus in Serra da Concórdia fed predominantly upon arthropods such as caterpillars, isopods, and spiders. Those relatively soft-bodied prey are among the main food items typically consumed by lizards in this genus- $-E$. bilineatus: Zamprogno et al. 2001, Teixeira et al. 2005, E. boulengeri (= E. brasiliensis): Teixeira et al. 2005, E. brasiliensis: Van Sluys et al. 2004, Dorigo et al. 2014, E. catenatus: Vanzolini 1972, E. iheringii: Marques and Sazima 2004, Rautenberg and Laps 2010, E. leechii: Vitt et al. 1996, E. perditus: Sousa and Cruz 2008, Sturaro and Silva 2010, Barreto-Lima and Sousa 2011. Enyalius perditus in Serra da Concórdia 
Table 1. Number $(N)$, volume $\left(\mathrm{V}\right.$, in $\left.\mathrm{mm}^{3}\right)$, and frequency of occurrence $(F)$ of each prey category consumed by Enyalius perditus $(N=8)$ in the Atlantic Forest of the Santuário de Vida Silvestre da Serra da Concórdia, in the municipalities of Barra do Piraí and Valença, state of Rio de Janeiro, southeastern Brazil. Percentages shown in parentheses. (*) Wasp pupae.

\begin{tabular}{|c|c|c|c|}
\hline Item & $N(\%)$ & V (\%) & $F(\%)$ \\
\hline GASTROPODA & $1(1.8)$ & $557.3(16.2)$ & $1(12.5)$ \\
\hline \multicolumn{4}{|l|}{ ARACHNIDA } \\
\hline Araneae & $2(3.5)$ & $611.5(17.8)$ & $2(25.0)$ \\
\hline \multicolumn{4}{|l|}{ MALACOSTRACA } \\
\hline Isopoda & $30(52.6)$ & $374.6(10.9)$ & $3(37.5)$ \\
\hline \multicolumn{4}{|l|}{ HEXAPODA } \\
\hline Orthoptera & $2(3.5)$ & $99.0(2.9)$ & $2(25.0)$ \\
\hline Coleoptera (larvae) & $2(3.5)$ & $212.7(6.2)$ & $2(25.0)$ \\
\hline Formicidae & $2(3.5)$ & $2.0(<0.1)$ & $1(12.5)$ \\
\hline Hymenoptera* & $7(12.3)$ & $22.2(0.6)$ & $2(25.0)$ \\
\hline Lepidoptera (larvae) & $10(17.5)$ & $1106.7(32.1)$ & $6(75.0)$ \\
\hline Diptera & $1(1.8)$ & $85.0(2.5)$ & $1(12.5)$ \\
\hline ARTHROPOD REMAINS & - & $369.1(10.7)$ & - \\
\hline Plant MATERIAL & - & $4.5(0.1)$ & $2(25.0)$ \\
\hline Total & $57(100)$ & $3444.6(100)$ & $8(100)$ \\
\hline
\end{tabular}

consumed nine types of arthropod prey categories, which is comparatively less than the number of prey eaten by individuals of this species in other populations (Souza and Cruz 2008, Barreto-Lima 2009, Sturaro and Silva 2010, Barreto-Lima and Sousa 2011). This difference could be due to the relatively low number of lizards examined in comparison with the previous studies.

In Serra da Concórdia, no samplings were performed for estimation of potential prey availability for E. perditus, so it was not possible to assess whether lizards consumed food items selectively or according to their local abundance.
However, estimates of local prey availability for other populations of E. perditus have suggested that these lizards might select their food despite the wide variety of prey types available in the environment (Sousa and Cruz 2008, Sturaro and Silva 2010). No pronounced variation in the main types of arthropod prey consumed by these lizards among populations has been detected, despite potential differences in prey abundance among environments (Sousa and Cruz 2008, Sturaro and Silva 2010, Barreto-Lima and Sousa 2011; all through analyses of stomach contents), which might indicate some level of selective foraging behavior. 
Individuals of $E$. perditus from Serra da Concórdia consumed fragments of dead leaves, fed on prey taxa commonly found in leaf litter (e.g., Isopoda, Coleoptera larvae), and were sometimes found on the ground or captured in pitfall traps during fieldwork, which suggests that these lizards use the forest floor leaf litter for foraging and other activities. Enyalius perditus has been observed foraging on the forest floor, which may be the microhabitat most frequently used by this species (Barreto-Lima et al. 2013). Previously, species of the genus Enyalius were considered as primarily arboreal lizards (Etheridge 1969). However, increasing evidence indicates that these animals also move and forage on the forest floor (Vanzolini 1972, Vitt et al. 1996, Sousa et al. 2000, Zamprogno et al. 2001, Marques and Sazima 2004, Van Sluys et al. 2004, Teixeira et al. 2005, Sousa and Cruz 2008, Rautenberg and Laps 2010, Sturaro and Silva 2010, Barreto-Lima and Sousa 2011, Barreto-Lima et al. 2013, Dorigo et al. 2014). Enyalius perditus lizards were also sighted using perches above ground level (varying from 30 to $200 \mathrm{~cm}$ ) in Serra da Concórdia. Therefore, our study provides additional information and reinforces the idea of the use of both vegetation and leaf litter of forest floor by Enyalius lizards.

\section{Acknowledgments}

We thank Ross MacCulloch for his valuable contributions. This study was sponsored by Critical Ecosystem Partnership Fund (CEPF), Conservação Internacional and Aliança para a Conservação da Mata Atlântica. We thank The Santuário Ecológico da Serra da Concórdia and the Grupo de Proteção Ambiental da Serra da Concórdia (Salveaserra), through its Director, Roberto Lamego, for the local permit for the study and logistic support. We thank the Conselho Nacional de Desenvolvimento Científico e Tecnológico (CNPq), which provided grants to CFDR (processes 304791/2010-5, 02974/2015-6, and 472287/2012-5) and to MCK (process 150353/2003-0), the Fundação Carlos
Chagas Filho de Amparo à Pesquisa do Estado do Rio de Janeiro (FAPERJ) which supports CFDR through the Programa Cientistas do Nosso Estado (processes E-26/102.765/2012 and E-26.202.920/2015), and the Coordenação de Aperfeiçoamento de Pessoal de Nível Superior (CAPES), which granted a PhD scholarship to TMC and TAD, and a MSc scholarship to TMT. Lizards were collected under ICMBio license (number 17474-1).

\section{References}

Attias, N., D. S. L. Raíces, F. S. Pessoa, H. Albuquerque, T. Jordão-Nogueira, T. C. Modesto, and H. G. Bergallo. 2009. Potential distribution and new records of Trinomys species (Rodentia: Echimyidae) in the state of Rio de Janeiro. Zoologia 26: 305-315.

Barreto-Lima, A. F. 2009. Gastric suction as an alternative method in studies of lizard diets: tests in two species of Enyalius (Squamata). Studies on Neotropical Fauna and Environment 44: 23-29.

Barreto-Lima, A. F. and B. M. Sousa. 2006. Court and copulation behaviors of Enyalius perditus Jackson, 1978 (Squamata, Leiosauridae) in captivity conditions. Revista Brasileira de Zoociências 8: 193-197.

Barreto-Lima, A. F. and B. M. Sousa. 2011. Feeding ecology and sexual dimorphism of Enyalius perditus in an Atlantic forest, Brazil. Herpetological Bulletin 118: 1-9.

Barreto-Lima, A. F., G. M. Toledo, and L. A. Anjos. 2012. The nematode community in the Atlantic rainforest lizard Enyalius perditus Jackson, 1978 from southeastern Brazil. Journal of Helminthology 86: 395-400.

Barreto-Lima, A. F., E. O. Pires, and B. M. Sousa. 2013. Activity, foraging mode and microhabitat use of Enyalius perditus (Squamata) in a disturbed Atlantic rainforest in southeastern Brazil. Salamandra 49: 177185.

Costa, H. C., and Bérnils, R. S. 2014. Répteis brasileiros: lista de espécies. Herpetologia Brasileira 3: 74-84.

Corn, P. S. 1994. Straight-line drift fences and pitfall traps. Pp. 109-117 in W. R. Heyer, M. A. Donnelly, R. W. McDiarmid, L. A. C. Hayek, M. S. Foster (eds.), Measuring and Monitoring Biological Diversity: Standard Methods for Amphibians. Washington. Smithsonian Institution Press. 
Crump, M. L. and N. J. Scott Jr. 1994. Visual encounter surveys. Pp. 84-92 in W. R. Heyer, M. A. Donnelly, R. W. McDiarmid, L. A. C. Hayek, M. S. Foster (eds.), Measuring and Monitoring Biological Diversity: Standard Methods for Amphibians. Washington. Smithsonian Institution Press.

Dorigo, T. A., T. Maia-Carneiro, M. Almeida-Gomes, C. C. Siqueira, D. Vrcibradic, M. Van Sluys, and C. F. D. Rocha. 2014. Diet and helminths of Enyalius brasiliensis (Lacertilia, Iguania, Leiosauridae) in an Atlantic rainforest remnant in southeastern Brazil. Brazillian Journal of Biology 74: 199-204.

Dunham, A. E. 1983. Realized niche overlap, resource abundance, and intensity of interspecific competition. Pp. 261-280 in R. B. Huey, E. R. Pianka, and T. W. Schoener (eds.), Lizard Ecology: Studies of a Model Organism. Cambridge. Harvard University Press.

Durette-Desset, M. C., L. A. Anjos, and D. Vrcibradic. 2006. Three new species of the genus Oswaldocruzia Travassos, 1917 (Nematoda, Trichostrongylina, Molineoidea) parasites of Enyalius spp. (Iguanidae) from Brazil. Parasite 13: 155-125.

Etheridge, R. 1969. A review of the iguanid lizard genus Enyalius. Bulletin of the British Museum, Natural History, Zoology 18: 233-260.

Jackson, J. F. 1978. Differentiation in the genera Enyalius and Strobilurus (Iguanidae): implications for Pleistocene climatic changes in eastern Brazil. Arquivos de Zoologia, Museu de Zoologia da Universidade de São Paulo 30: $1-79$.

Jaeger, R. G. and R. F. Inger. 1994. Quadrat sampling. Pp. 97-102 in W. R. Heyer, M. A. Donnelly, R. W. McDiarmid, L. A. C. Hayek, M. S. Foster (eds.), Measuring and Monitoring Biological Diversity: Standard Methods for Amphibians. Washington. Smithsonian Institution Press.

Johnson, N. F. and C. A. Triplehorn. 2004. Borror and Delong's Introduction to the Study of Insects. $7^{\text {th }}$ edition. Belmont. Cengage, Brooks Cole. 888 pp.

Marques, O. A. V. and I. Sazima. 2004. História natural dos répteis da Estação Ecológica Juréia-Itatins. Pp. 257-277 in O. A. V. Marques and W. Duleba (eds.), Estação Ecológica Juréia-Itatins: Ambiente Físico, Flora e Fauna. Ribeirão Preto. Holos Editora.

Rautenberg, R. and R. R. Laps. 2010. Natural history of the lizard Enyalius iheringii (Squamata, Leiosauridae) in southern Brazilian Atlantic forest. Iheringia, Série Zoologia 100: 287-290.
Sousa, B. M. and C. A. G. Cruz. 2008. Hábitos alimentares de Enyalius perditus (Squamata, Leiosauridae) no Parque Estadual Ibitipoca, Minas Gerais, Brasil. Iheringia, Série Zoologia 98: 260-265.

Sousa, B. M., C. A. G. Cruz, R. M. H. Carvalho, and M. N. Silva. 2000. Descrição do processo de muda em Enyalius perditus Jackson (Reptilia, Sauria, Polychrotidae). Revista Brasileira de Zoologia 17: 225-228.

Sousa, B. M., A. Oliveira, and S. S. Lima. 2007. Gastrointestinal helminth fauna of Enyalius perditus (Reptilia: Leiosauridae): relation to host age and sex. Journal of Parasitology 93: 211-213.

Sturaro, M. J. and V. X. Silva. 2010. Natural history of the lizard Enyalius perditus (Squamata: Leiosauridae) from an Atlantic forest remnant in southeastern Brazil. Journal of Natural History 44: 1225-1238.

Teixeira, R. L., K. Roldi, and D. Vrcibradic. 2005. Ecological comparisons between the sympatric lizards Enyalius bilineatus and Enyalius brasiliensis (Iguanidae, Leiosaurinae) from an Atlantic Rain-Forest area in southeastern Brazil. Journal of Herpetology 39: 504 509.

Van Sluys, M., V. M. Ferreira, and C. F. D. Rocha. 2004. Natural history of the lizard Enyalius brasiliensis (Lesson, 1828) (Leiosauridae) from an Atlantic Forest of southeastern Brazil. Brazilian Journal of Biology 64: $353-356$.

Vanzolini, P. E. 1972. Miscellaneous notes on the ecology for some Brazilian lizards (Sauria). Papéis Avulsos de Zoologia 26: 83-115.

Vitt, L. J., T. C. S. Ávila-Pires, and P. A. Zani. 1996. Observations on the ecology of the rare Amazonian lizard, Enyalius leechii (Polychrotidae). Herpetological Natural History 4: 77-82.

Vrcibradic, D., L. A. Anjos, J. J. Vicente, and C. R. Bursey. 2008. Helminth parasites of two sympatric lizards, Enyalius iheringii and E. perditus (Leiosauridae), from an Atlantic rainforest area of southeastern Brazil. Acta Parasitologica 53: 222-225.

Zamprogno, C., M. G. F. Zamprogno, and R. L. Teixeira. 2001. Evidence of terrestrial feeding in the arboreal lizard Enyalius bilineatus (Sauria, Polychrotidae) of south-eastern Brazil. Revista Brasileira de Biologia 61: $91-94$.

Editor: Steven Poe 